\title{
Role of insulin and IGF1 receptors in proliferation of cultured renal proximal tubule cells
}

\author{
Bonnie L. Blazer-Yost. Melanie Watanahe. Thonias $\mathbf{P}$. Haverty and Fuad N. Ziyadeh

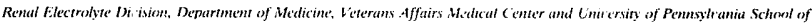

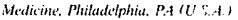 \\ (Received 28 May 1991) \\ (Revised manuscript received 10 September ivyl)
}

Key words: Kidney growth: Mitogenesis; Fpidermal growth factor: (ompetitiv hinding assay: (Mouse cortical tubule)

We have used a murine proximal tubule cell line (MCT cells) to determine the presence and binding characteristics of insulin and IGF1 receptors and to correlate these parameters with the concentration-response relationships for ligand-induced cellular proliferation. Separate insulin and ICFI receptors were identified by equilibrium binding assays. Half-maximal displacement of either peptide encurred at 3-10 nM; crossover binding to the alternate receptor occurred with a 10 - to 100 -fold lower affinity. Peptide effects on cellular proliferation were determined by measuring $\left[{ }^{3} \mathrm{H}\right]$ thymidine incorporation. Both insulin and IGFI stimulate thymidine incorporation in a dose-dependent manner with similar increases above the basal level. The estimated half-maximal stimulation $\left(\mathbf{E C}_{50}\right)$ occurred at $4 \mathrm{nM}$ for IGFI and $8 \mathrm{nM}$ for insulin. A comparison of the receptor binding afinities with the dose-response relationships for $\left[{ }^{3} \mathrm{H}\right]$ thymidine incorporation reveais that each growth factor appears to be exerting its effect via binding to its own receptor. Therefore, in this cell line, physiologic concentrations of either insulin or IGFI can modulate cellular growth. To our knowledge this is the first demonstration of a mitegenic effect whicl! may be modulated by ligand binding to the insulin receptor in proximal tubule epithelia.

\section{Introduction}

Insulin and insulin-like growth factor 1 (IGF1) are structurally related peptides whose functions are thought to have diverged during evolution. In genera!, insulin functions as an endocrine hurmone which is critical in the control of carbohydrate, protein and lipid homeostasis. In contrast, IGFI is classictily considered a regulator of cellular growth and differestiation. Interestingly, however, in certain tissues the two peptides can also mediate similar cellular effects such as the stimulation of substrate and ion transport $[1-3]$ and cellular proliferation [4-8].

Each peptide binds with high affinity to distinct receptors and it is this specific ligand-receptor interaction which initiates the physiological effects of the

Abbreviaiions: IGFI, insulin-like growth factor I; MCT cells, murine proximal tubule cell line; PACE, polyasrylamide gel electrophoresis: SDS. sodium dodecyl sulfate.

Correspondence: B.L. Blazer-Yost. Renal Research. Room A303R. Veterans Affairs Medical Center, University and Woodland Aves., Philadelphia, PA 19104, U.S.A. peptide. Overall the insulin and IGFI receptors share remarkable homology both in primary structure and in organization. Not surprisingly, therefore, insulin and IGF1 exhibit crossover binding to the heierologous receptor, however, crossover binding occurs with a significant (10-100-fold) decrease in affinity [3,9-11]. The crossover binding phenomenon is often evoked to explain an apparent crossover in physiological effect. For example, insulin is a required component for growth of mammatian cells which are maintained in iissue culture using serum-free, defined media. Typically the growth-stimulatory effects of insulin are achieved at pharmacologic concentrations $(1 \mu \mathrm{g} / \mathrm{ml}$ or greater) [12-18]. In contrast, the efferts of IGF1 on cellular proliferation are often manifested at much lower (i.e., physiological) concentrations $[2,9,11]$. These findings suggest that the growth stimulatory effects of both insulin an.1 IGF1 are manifested via binding to the IGFI receptor. In contrast, several recent studies have suggested that in certain fibroblastic cell types both insulin and IGFI can modulate cell growth via binding to their homologous receptors [5].

Insulin and GCr! receptors co-exist on the same cells in many tissues. In the manmatian kidney, both 
receptors have been demonstrated on glomerular mesangial cells [2] and proxirnal tubular epithelial cells $[19,20]$. In addition, in renal tissue, both insulin and IGF1 have been demonstrated to stimulate solute and fluid reabsorption $[3,21-23]$ as well as promote growth in cell culture $[24,25]$. The co-existence of two receptors, each capable of binding either ligand, necessitates a careful correlation of binding affinities with physiological effect before a functional response can be ascribed to activation of either receptor.

In this study we used a proximal tubule cell line to test whether cellular proliferation is modulated by ligand binding to insulin and/or IGF1 receptors. The mouse cortical tubule (MCT) line was originally derived from inicrodissected proximal tubule segments from normal mice, immunoselected into a homogeneous cell population and stabilized in long-term culture by SV40 trainsformation [26]. This is a well cheracterized ceil line which has proven to be a good model in which to investigate growth of proximal tubule cells under a variety of metabolic $[27,28]$ and hormonal conditions [29]. Portions of this work have been presented in absiract form: Blazer-Yost, B.L., Watanabe, M., Haverty, T. and Ziyadeh, F.N. (1990) J. Am Soc. Nephrol. 1, 453A.

\section{Materials and Methods}

Media for cell culture were obtained from Gibso (Grand lsland, NY). Recombinant huinan IGF1 (THR59) u'as purchesed frum AMGer Biologicais (Thousand Oaks, CA). IGFI stock solutions $(\mu \mathrm{M})$ were prepared in $0.01 \mathrm{M} \mathrm{HCl}$ and stored at $5^{\circ} \mathrm{C}$. IGFI was iodinated to a specific activity of $1600-2300 \mathrm{Ci} / \mathrm{mmol}$ using a modified chloramine-T procedure [30]. Porcine insulin was kindly provided by Lilly Research (Eli Lilly, Indianapolis, IN). Insulin stock soiutions $(\mathrm{mM})$ were prepared in $0.005 \mathrm{M} \mathrm{HCl}$ and stored at $5^{\circ} \mathrm{C}$. ${ }^{125} \mathrm{I}$-labeled porcine insulin, $2200 \mathrm{Ci} / \mathrm{mmol}$, was purchased from New England Nuclear (Boston, MA). $\left[{ }^{3} \mathrm{H}\right]$ Thymidine, 5 $\mathrm{Ci} / \mathrm{mmol}$, was obtained from Amersham (Arlington Heights, IL). Disuccinimidyl suberate was obtained from Pierce Chemical (Rockford, IL). Disuccinimidyl suberate stock $\left(5 \cdot 10^{-3} \mathrm{M}\right)$ was prepared in DMSO immediately beforc use. Electrophoresis grade reagents for polyacrylamide gel electrophoresis (PAGE) were purchased from Bio-Rad (Richmond CA). All other reagents were highest quality available and were obtained from commercial sources.

Cell Culture. The isolation and characterization of the MCT cell line were provided previously [26]. Multiple morphological and functional properties of this cell line are consistent with those of differentiated proximal tubule epithelial cells [26-28]. Briefly, the cells stain positive for cytokeratin and alkaline phosphatase and demonstrate apical microvilli and lateral tight junctions by electron microscopy. The cells respond to treatment with parathyroid hormone by an increase in cyclic AMP content [29]. In the studies described here, the culture medium was a 1:1 mixture of Dulbecco's modified Eagle's medium (DMEM) and Ham's-F12 (HF12), supplemented with $100 \mu \mathrm{g} / \mathrm{ml}$ streptomycin, $100 \mathrm{U} / \mathrm{ml}$ penicillin, $2 \mathrm{mM}$ glutamine and $5 \mu \mathrm{g} / \mathrm{ml}$ human transferrin. The cells were passaged every $48-72$ $h$ and were carried in culture medium supplemented with $10 \%$ inactivated fetal calf serum. Cultures were maintained in a humidified atmosphere of $5 \% \mathrm{CO}_{2}$ at $37^{\circ} \mathrm{C}$

Competitive binding studies. In those experiments where competitive binding of insulin and IGFI to MCT cells was determined, the cells were seeded onto 24 well rissue culture plates (density $=10^{5}$ cells/well). The cells were maintained in normal media for $24 \mathrm{~h}$, then placed in serum-free media for $24-48 \mathrm{~h}$ prior to assay. Confluent cellular monolayers were washec: and incubated at room temperature for $90 \mathrm{~min}$ in bindiing bufier (serum-free medium, 0.2\% BSA, $25 \mathrm{mM}$ Hepes, $\mathrm{pH}$ 7.4) containing (3-4) $\cdot 10^{-10} \mathrm{M}\left[{ }^{125} 1\right]$ insulin or [ $\left.{ }^{125} 1\right]$ IGF1 and unlabeled competing peptides as indicated. At the end of the incubation period, the cells were washed three times with ice-cold phosphatebuffered saline and solubilized in $1 \mathrm{M} \mathrm{NaOH}, 0.1 \%$ Triton X-100. Aliquots of the solubilized celiular material were counted in a gamma scintillation coutter. Nonspecific binding was defined as the number of counts bound in the presence of $10^{-7} \mathrm{M}$ unlabeled peptide and this value was subtracted from all samples. In every experiment duplicate or iriplicate assay wells were performed for each concentration. Nonspecific binding was less than $20 \%$ of total binding.

To further define the binding specificities of the receptor subunits, cells were incubated in binding buffer with (3-4) $10^{-111} \mathrm{M}\left[{ }^{125} \mathrm{I}\right] \mathrm{IGF} 1$ in the presence or absence of unlabeled competing peptides. After a 90 min incubation period at room temperature, the cells were washed twice with cross-linking buffer $(0.1 \mathrm{M}$ Hepes, $0.12 \mathrm{M} \mathrm{NaCl}, 5 \mathrm{mM} \mathrm{KCl}, 1.2 \mathrm{mM} \mathrm{MgSO}, 8$ $\mathrm{mM}$ glucose and $10 \mathrm{mg} / \mathrm{ml} \mathrm{BSA}, \mathrm{pH} 8.0$ ). The bound peptide was covalently cross-linked to the receptor by a $15 \mathrm{~min}$ incubation with $0.1 \mathrm{mM}$ freshly prepared disuccinimidyl suberate in crosslinking buffer. The reaction was terminated by the addition of $0.1 \mathrm{M}$ Tris ( $\mathrm{pH} 8.8$ ). The cells were washed and solubilized in SDS-PAGE buffer (3\% SDS, $10 \%$ glycerol, $1 \% \beta$-mercaptoethanol, $0.05 \mathrm{M}$ Tris, pH 6.8). The solubilized samples were stored at $-20^{\circ} \mathrm{C}$.

$P A G E$. SDS-PAGE was performed on $15 \times 13 \mathrm{~cm}$ slab gels with a linear 5-15\% acrylamide gradient and a $4 \%$ stacking gel. The aliquots applied to the gel were matched for cell number. The preparations were subjected to electrophoresis under constant current conditions $(30 \mathrm{~mA} / \mathrm{gel}$ for $20 \mathrm{~min}$ followed by $25 \mathrm{~mA} / \mathrm{gel}$ 
for $4 \mathrm{~h}$ ). The gels were then fixed, dried and exposed to Kodak XAR-5 film in cassettes containing X-Omatic fine intensifying screcns (Eastman Kodak. Rochester. NY).

$/{ }^{3} H /$ Thymidine incorporation studies. Cells in culture were released by trypsin-EDTA, washed twice in serum-free medium and adjusted to a final concentration of $1 \cdot 10^{6}$ celis $/ \mathrm{ml}$. 10000 cells were subcultured in flat-bottom 96-microtiter wels, each containing $200 \mu \mathrm{I}$ serum-free medium. After $48-72$ h of quiescence the media were removed and replaced with fresh serumfree medium without or with the addition of various concentrations of insulin or IGFI as noted in the text. All growth studies were performed on rested cells at approx. $70 \%$ subconfluence. Cells were allowed to grow for an aduitional $24 \mathrm{~h}$. During the last 6 in of culture, the cells were pulsed with [ $` 4]$ thymidine $(1 \mu \mathrm{Ci} /$ well $)$. The media were removed and the cells were released with trypsin-EDTA for subsequent lysis and collection with a cell harvester (Brandel, Gaithersburg, MD) onto glass-microfiber fitici paper (934-AH, Whatman, U.K.). The incorporated radioactivity in cellular nuclei was assayed by counting filters in scintillation ocktail. $\left[{ }^{3} \mathrm{H}\right]$ Thymidine incorporation into cell DNA wais taken as an index of cell proliferation and was expressed in counts per min per well. Each experimental condition was tested in four to six replicate wells and the mean was taken to represent an individual experiment. In parallel experiments, measurements of cell number were performed in order to verify that the observed increase in thymidine incorporation was associated with an increase in cell number.

Statistics. The data are presented as means \pm S.E. with $n$ indicating the number of different experiments. Comparisons were performed using Student's $t$-test for paired or unpaired values as appropriate; values of $P<0.05$ were considered significant. Binding studies were analyzed graphically.

\section{Results}

\section{Competitive binding studies}

Equilibrium binding assays were performed to determine the presence and specificity of insulin and IGF1 receptors on MCT cells. Fig. 1 illustrates the specificity of human recombinant IGFI binding: half maximal displacement of [ ${ }^{125}$ I] IGF1 ucuurs at an unlabeled IGF1 concentration between 3 and $10 \mathrm{nM}$. Insulin was an effective competitive ligand only at approx. 100-fold greater concentrations. Fig. 2 illustrates the specificity of binding of porcine insulin: half maximal displacement of $\left[{ }^{125} 1\right]$ insulin occurs at an unlabeled insulin concentration between 3 and $10 \mathrm{nM}$. IGF1 also displaced irisulin but only at approx. 10-30fold greater concentrations. Thus, the affinity of insulin for the insulin receptor is very similar to that of IGFI

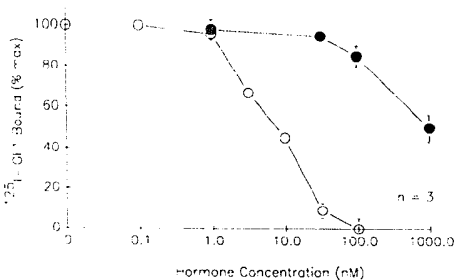

Fig. 1. Competitive binding curve for [ $\left.^{126} 1\right]$ IGFI in the moese proximat iubule cell line. Maximal binding is defined as the anount of [ ${ }^{125}$ I]IGFI specifically bound by intact cells in the absence of ualsbeled peptide. [ ${ }^{125}$ J]JGFI hound in the presence of various concentrations of unlabeled competing ligands is expressed as a pereentage of the maximal level ( $r$; max). Nonspecific binding is defined as the number of counts bound in the presence of $100 \mathrm{nM}$ IGFI and is subtracted from all values. Points shown at each concentration represent the mean of three separate experiments. The standard error of the mean is indicated by vertical bars. When ne tars appear. the standard errot is less than the symbol used to designate the mean value. $\curvearrowright-0$. IGF1: - insulin.

for the IGFI receptor; crossover binding to each receptor does occur but only with a 10 - to 100 -iold lower affinity.

The relative number of insulin and IGF1 receptors appears to differ in MCT cells. Using our standard incubation conditions with approximately equal concentrations of peptides which had been iodinated to a

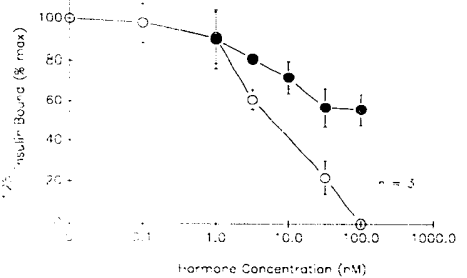

Fig. 2. Competitive binding curve for [ ${ }^{12}$ ? finsulin in the mouse proximal tubule cell line. Maximal binding is defined as the amount of [ $\left.{ }^{25} 1\right]$ insulin specifically bound by intact celis in the absence of unlabeled peptide. [ $\left.{ }^{12} \mathrm{I}\right]$ Insulin bound in the presence of various concentrations of unlabeled competing ligands is expressed as a percentage of the maximal level ( $\%$ max). Nonspecific binding is defined as the number of counts bound in the presence of $100 \mathrm{nM}$ insulin and is subtracted from all values. Points shown at each concentration represent the mean of three separate experiments. The standard errot of the mean is indicated by vertical bars. When no bars appear, the standard error is less than the symbol used to designate the mean value, - IGF1: $0-0$. insulin. 


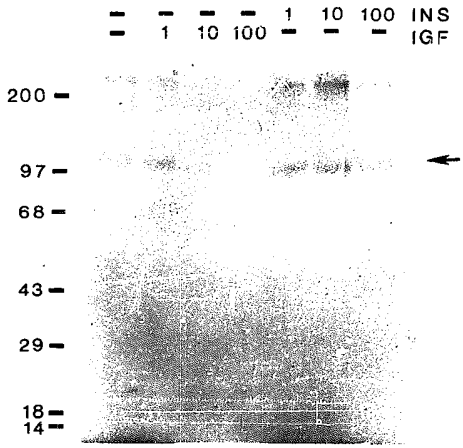

Fig. 3. [ ${ }^{1: 5}$ I]IGFl binding to mouse proximal tubule cell receptor subunits in the preserice of various concentr:tions of unlabeled IGFI and insulin. To show that receptor specificity was manifested the level of the $\alpha$ subunit of the IGFI receptor, selected samples from the competitive binding curves were treated with the crosslinking reagent disuccinimidyl suberate to covalently couple bound ligand to the receptor. The crosslinked samples were solubilized in a reducing buffer, separated by one-dimensional PAGE and visualized by rutoradiography. Unlabeled competing ligands (final concentrations indicated) were present in the incubation buffer before crosslinking. The arrow indicates the pesition of the $\alpha$ subunit of the recentot.

Positions of the molecular mass markers (in $\mathrm{kDa}$ ) are indicatc.

similar specific activity, 3-6\% of the [125 I]IGF1 was specifically bound by the MCT cells; in contrast, only $0.1-0.4 \%$ of the $\left[{ }^{125}\right.$ I] insulin was specifically bound in this cell line.

To show that the binding specificity was manifested at the level of the $\alpha$-subunits of the MCT receptors, in some competitive binding experiments the bound IGF1 was crosslinked to the receptor with disuccinimidyl suberate. Fig. 3 illustrates [ $\left.{ }^{125} 1\right]$ IGF1 binding to MCT cells in the presence of various concentrations of unlabeled IGF1 or insulin. Maximal ${ }^{125} \mathrm{I}$ incorporation into proteins having an apparent molecular mass of 130 $\mathrm{kDa}$ is observed in samples incubated with no competing ligand or with $1 \mathrm{nM}$ unlabeled IGFl. As anticipated from the competitive binding curves, $100 \mathrm{nM}$ unlabeled IGFI completely inhibited the binding of [ ${ }^{125}$ I]IGF1, whereas $10 \mathrm{nM}$ IGF1 partially inhibited binding. $100 \mathrm{nM}$ unlabeled insulin only slightly inhibited the binding of $\left.{ }^{125} I\right][G F 1$. The presence of low concentrations of insulin ( 1 atd $10 \mathrm{nM}$ ) did not inhibit and may stimulate [ ${ }^{125}$ I]IGF1 incorporation. The basis for this apparent increase in IGF1 binding in the presence of physiological concentrations of insulin is unknown. The diffuse high molecular mass $(>200$ $k D a)$ : and $i$, these studies likely results from the crosslinking of $\Omega / \beta$ and/or $\alpha / \alpha$ receptor subunits by the divalent crosslinking reagent, disuccinimidyl sub,rate [2]. Due to the extremely low number of insulin receptors, we were unabie to incorporate sufficient $\left[{ }^{125} I\right]$ insulin to analyze the $\left[{ }^{125} I\right]$ insulin binding curves by PAGE.

\section{$I^{3} \mathrm{H} /$ Thymidine incorporation studies}

Peptide effects on cellular proliferation were determined by measuring $\left[{ }^{3} \mathrm{H}\right]$ thymidine incorporation in the presence of various concentrations of insulin and IGF1 (Fig. 4). Both insulin and IGF1 stimulated thimidine incorporation in a dose-dependent manner vith similar maximal increases above the basal level. The estimated half-maximal stimulation $\left(\mathrm{EC}_{50}\right)$ is $4 \mathrm{nM}$ for IGF1 and $8 \mathrm{nM}$ for insulir; these concentrations f $\mathrm{f}$ !l within the physiologic range of either peptide.

A maximal effect of IGF1 on celiular proliferation appears to be manifested within a narrow concentration range. Maximal $\left[{ }^{3} \mathrm{H}\right]$ thymidine incorporation was achieved at $10 \mathrm{nM}$ and further increases in peptide concentration result in a submaximal proliferative response (Fig. 4).

To confirm the ability of insulin to stimulate cell proliferation, pà ailici suivconfluent cultures in 12-well piastic plates were incubated in the presence and $a b$ sence of $32 \mathrm{nM}$ insulin. At the end of the $48 \mathrm{~h}$ incubation period the control cultures contained 6.75 $\pm 0.36 \cdot 10^{5}$ cells/well while the insulin treated cultures contained $8.95 \pm 0.61 \cdot 10^{5}$ cells $/$ well $(n=5, P<$ 0.05 ).

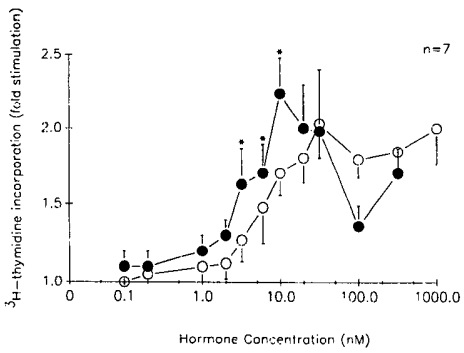

Fig. 4. Comparison of tritiated thymidine incorporation in response to insulin and IGF1 in proximal tubule celts. $\left[{ }^{3} \mathrm{H}\right]$ Thymidine incorporation in resposse to various concentrations of insulin and IGFI is expressed relative to control cultures which were incubated in serum-free media during the experimental period. $\mathrm{Th}$ : data shown represent seven separate experiments. Thi stindard errors of the mean are indicated by vertical bars. * indicates concentrations where the responses to insulin and IGFI are statistically different $(P<0,02)$. $\circ \longrightarrow$, insulin; $\bullet$ IGFI. 


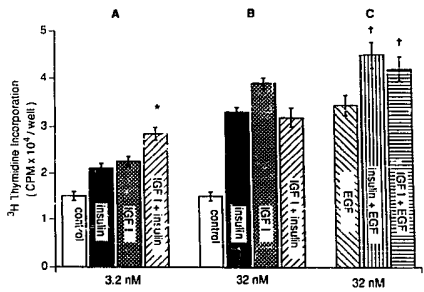

Fig. 5. Respoise of tritiated thymidine incosporation in proximal tubule cells to the combined treatme:tt with IGFi. insulin and EGF. The bars illustrate the counts of $\left[{ }^{3} \mathrm{H}\right]$ thymidine incorporated by the cultured cells in response to submaximal concentrations of insulin and IGFI $(\mathrm{N})$, maximal concentrations of insulin and IGFI (B) ind a maximal concentration of EGF $(10 \mathrm{ng} / \mathrm{ml})$ in combination with maximal concentrations of insulin and IGF! (C). The vertical lines represent standard errors of the mean. The combined treatment with submaximal doses of IGF1 and insulin elicits an additive effect on thymidine incorporation which is significantly $\{P<0,(15)$ higher then that exhibited by either hormone alone $(*)$. When maximal doses of either IGFI or insulin are combined with epidertal growth factor (EGF, 10 $\mathrm{ng} / \mathrm{mi}$ ), the stimulation in thymidine incorporation is significantly $(P<0.05)$ highet than that exhihited by treatment with EGF alone (+).

We have also exanined the proliferative response to incubation with combinations of insulin, IGFl and epidermal growth factor (EGF) (Fig. 5). Incubation with submaximal doses of IGFI and insulin (3.2 nM) resulted in a significantly higher stimulation of thymidine incerporation compared to that elicited by either hormone alone. In contrast, the combined treatment with maximal doses of IGFI and insulin ( $32 \mathrm{nM}$ ) produced a proliferative stimulation that was not different from the response to either hormone alone. When maximal doses of either IGF1 or insulin (32 $\mathrm{nM}$ ) are combined with epidermal growth factor $(10 \mathrm{ng} / \mathrm{ml})$, the stimulation in thynidine incorporation was significantly higher than that exhibited by treatment with EGF alone. A combination of maximal doses of EGF and IGF1 (or insulin) also stimulates thymidine incorporation to a significantly higher $(P<0.05)$ level than either IGFI or insulin alone (data not shown).

\section{Discussion}

In the kidney insulin is thought to modulate metabolic and transport functions while IGFI is con. sidered to be a regulator of growth and differentiation $[21,31,34]$. Many of the studies which have given rise to this general concept have used intact organs or membranes isolated from specific areas of the kidney. While such studies have been extremely valuable in establishing the functions of various nephron segments, it is difficult to precisely determine the role of growth factors and metabolic modulators in thesc experimental systems. A continuous cell line derived from a defined area of the kidney tubule provides the cellular homogenciiy and stability necessary to assess the contribution of various factors to the growth of a specific cell typc. In this study we uscd the MCT cell line as a model for proximal tubule cell growth. Previous investigations have demonstrated that this cell line retains the characteristics of differentiated proxintai tubule cells and provides a suitable model to investigate proliferation of renal epithelia [26-29].

While the physiological role of insulin in renal giuwth remains unclear, it is known that kidnev cells in cuiture require insulin in the supporting medium. Hormone-supplemented, serum-free medium has been described for maintenance of the Madin-Darby canine kidney (MDCK) cell line [12], the LLC-PK1 epithelial cell line from pig kidney [15], and for primary cultures of canine renal epithelia [13], baby mouse kidney cells [14] and rabbit kidney epithelial cells $[16,17]$. IGFI was not a component of the hormone supplements but insulin was present in micromolar concentratiois. The assumption, explicit or implicit, is that it these supraphysiological concentrations insulin modulates growth and differentiation via crossover binding to IGF1 receptors. However, this assumption may not be valid for all cell types.

Physiological concentrations of either insulin or IGFI promote cell growth and proliferation via bindin. to their homologous receptors in a rat osteosarcoma cell line, UMR-106-01 [8] and in Swiss 3T3 fibroblasts [6] as well as in normal skin fibroblasts in primary [4] and continuous [7] culture. In a careful study, Furianettc et al. ijj useúd specific anti-receptor antibodies to show that insulin, working via an insulin receptor, was not mitogenic in two lines of human embryonic lung fibroblasts but, under identical cunditions. was miiugenic in a human dermal fihrobiast cell line, a human embryonir skin fibroblast line and an osteogenic sarcoma cell linc. Thus, it appears that, although activation of IGF1 receptors is uniformly capable of mediating a mitogenic response, the ability of activated insulin receptors to stimulate proliferation is cell-specific.

Both insulin and IGF1 receptors have previously been demonstrated on proximal tubular epithelia $[19,20,32]$. In agreement with these studics, we have found that mouse proximal tubule cells in culture also contain two separate receptors, each with similar displacement curves (Figs. 1 and 2). The affinity of insulin for the insulin receptor is very similar to that of IGFI for the IGFI receptor; crossover binding does occur but only with 10-100-fold lower affinity. The displacement curves for insulin and IGFI binding to their specific receptors are very similar to those reported in other tissues and cell lines $[2,3,11,33]$. Insulin/IGF1 
hybrid receptors have been assembled in vitro [35] and have been identificd in NIH3T3 and HepG2 cells [36] and in transiected rodent cells which overexpress fiuman insulin and IGF1 receptors [37]. Our binding curves are consistent with the existance of separatc insulin and IGF1 receptor pepulations, however, we cannot rule out the existence of a small number of insulin/IGF receptor hybrids. The molecular weight of the a subunit of MCT cell IGF1 receptor is comparable to other IGF1 receptors [38] and the ligand binding specificity is manifusted at the level of the $\alpha$ subunit (Fig. 3).

In our studies the amount of IGI I specifically bound by the proximal tubulc cells was at least an order of magnitude greater than that of insulin indicating a relatively higher number of IGF1 receptors. This is similar to isolated rat renal tubules [33] and cultured rat renal mesangial cells where specific binding of [2.5 $\mathrm{I}] \mathrm{IGFI}$ was $>200$-fold higher than insulin binding [2]. In contrast, the specific binding of insulin was approx. 4-fold higher than that of IGF1 in proximal tubular basolateral meribranes prepared from canine kidneys [32]. It is unknown whether the differences in magnitude of receptor expression in the proximal tubule represents natural differences in species, heterogeneity in cell type found in intact kidney or changes in receptor expression during the process of ceilular immortalization.

Both insuiin and IGF1 stimulate $\left[{ }^{3} H\right]$ thymidine incorporation ir proximal tubule cells with an $\mathrm{EC}_{50}$ between 3 and $10 \mathrm{nM}$; a maximal dose of IGF1 stimulated thynidine incurporation 2.2-fold, while a maximal concentiation of insulin eliciced a 2-fold stimulaion. A conparison of the receptor-ligand binding affinities (Figs. 1 and 2) with the dose-response relationships for $\left[{ }^{3} \mathrm{H}\right]$ thymidine incorporation (Fig. 4) reveats that each growth factor appears to stimulate growth via binding to its own receptor. Therefore, in this proximal tubule cell line, physiologic concentrations of either insulin or IGF1 can modulate rellular growth. It is possible that the slightly higher potency and magnitude of stimulation by IGF1 is due to the higher density of the IGF1 receptor compared w'ith that of the insulin receptor.

To our knowledge this is the first demonstration of a mitogenic effect which may be modulated by ligand binding to the insulin receptor in proximal tubule epithelia. Very little, in general, is known regarding growth effects of insulin on epithelial cells. In contrast, IGFI has been implicated as a major growth factor in renit tissue. Renal hypertrophy is a manifestation of acromegaly [39] which is characterized by an increase in circulating IGF1 levels. In addition, in response to certain stimuli, such as the loss of renal mass, the cortical and medullary collecting duct cells of the mammalian kidney are known to synthesize IGF1 [34,40-42].
The demonstration of specitic receptors for IGFI in the proximal tubule support the concept of a paracrine 'loop' for IGF1 [34].

Interestingly. maximal stiinulation of $\left[{ }^{3} \mathrm{H}\right]$ thymidine incorporation occurs at all insulin concentrations measured at and above $32 \mathrm{nM}$, whereas IGF1 is only maximally effective over a very narrow concentration range. A similar sharp decrease in the magnitude of IGF1 stimulation of $\left[{ }^{3} \mathrm{H}\right]$ thymidine incorporation at peptide leve!s above $10 \mathrm{nN} /$ has been dernonstrated in cultured rat renal mesangial cells [z]. This relatively narrow effective conce tration range may be physiologically relevant. However, a complete understanding of this phenomenon is limited by imprecise measurements of effective in vivo concentrations of IGF1.

In vivo, insulin levels in the circulation vary widely and rapidly according to the metabolic requirements of the organism. Despite this fluctuation, the effective circulating concentraticn of insulin is known to be much lower than the total concentration of IGF1. IGF: inlike insulin, is bound by several high affinity, sclublc binding proteins which may modulate peptide-receptor interactions and, therefore, the effective circulating concentration is difficult to ascertain $[11,31]$. Also, in contrast to insulin, IGF1 is a paracrine or autocrine factor in the kidney [34].

Although the growth stimulatory responses to both insuiin and IGFl appear to be initiated by ligand binding to distinct receptors, the cascade of events that culminate in cell proliferation may overlap at a point subsequent to ligand-receptor binding. The stimulatory response to a combination of maximal concentrations of both insulin and IGFI is not statistically greater than the response to a maximal stimulation of either peptide alone (Fig. 5). This was not due to the inability of the epithelium to show a further increase in thymidine incorporation: a maximal concentration of EGF in combination with a maximal concentration of insulin stimulates MCT cells to a greater degree than either peptide alone.

A similar overlap in the intracellular pathways stimulated by insulin and IGFI has been observed in the toad urinary bladder, a model of the mammalian distal nephron [3]. In this high resistance epitheliurn insulin or IGF1 binding to distinct receptors stimulates transcellular $\mathrm{Na}^{+}$flux. The natriferic pathways activated by insulin and IGF1 appear to converge subsequent to ligand-receptor binding but prior to the inal transport step(s). The generality of this post-receptor convergence in intracellular pathways remains to be tested.

The role of IGFI as a renal growth factor has been delineated by various studies; the role of insulin in renal growth remains more elusive. The current data suggest that insulin may be an important factor in renal cell proliferation. This peptide may play a role in repair and recovery after insult or may be important as 
a maintenance factor during normal cpitheliz t turnover and regeneration; however, the exact functict of insulin-stimulated proliceration remains to he ds . lex!.

\section{Acknowledgements}

This work was supported by a Research Fouitrarion Grant from the University of Pennsylvania (33.P-Y.) and by grants from the National institute of Diabetes and Digestive and Kidney Diseases (DK-39565', the American Diabetes Association and the Diabetes Research Conter of the University of Pennsyivania (F.N.Z.). Vie express our appreciation to Dr. Richard Furlanetto for generously supplyi:1g [ ${ }^{12 *}$ I]IGFI and for helpful dis:ussions regarding the isceptor binding assays.

\section{References}

1 Yu, K. I. and Czech, M.P. (1984) J. Biol. Chem. 259, 3(190)-36)5,

2 Arnqvist. H.J., Bullerman, B.J. and King. G.L. (1988) ‘mt. J. Physiol. 254, C411-C416.

3 Blazer-Yost, B.L., Cox, M. and Furlanetto, R. (1989) Am. J. Physiol. 257, C612-C620.

4 Flier, J.S., Usher, P. and Moses, A.C. (1986) Proc. Natl. Acad. Sci. USA 83, 664-t.68.

5 Furlanetıo, R.W., DiCarło, J.N. and Wisehart, C. (1987) J. Clin. Endocrinol. Metab. 6: 114之-1149.

6 Corps, A.N. and Brown, K.D. (1988) Biochem. 1. 252. 119-125.

7 Conover, A., Hirtz, R.L. and Rosenftld, R.G. (1989) Hoim. Metabol. Re:. 21, 59-63.

8 Hickinan, J. and McElduff, A. (1989) Endocrinology 124, 701-70h.

9 Froesch, E.R., Schmid, C., Schwander. J. and Zapf, J. (1985) Annu. Rev. Physiol. 47, 443-467.

10 Fujita-Yamaguchi, Y., LeBon, T.R., Tsubokawa, iv.. Henze!, W., Kathuria, S., Koyal. D. and Ramachandran, j. (i98ó) J. Biusi. Chem. 261, 16727-16731.

11 Humbel, R.E. (1990) Eur. J. Biorhem. 190, 445-462.

12 Taub, M., Chuman. L., Sair, M.H. Jr. and Sato. G. (1979) Proc. Natl. Acad. Sci. USA 76, 3338-3342.

13 Jefferson, D.M., Cobb, M.H., Gennaro, J.F., Jr. and Scott, W.H. (1980) Science $210,912-1,14$.

14 Taub, M. and Sato, G. (1980) J. Cell. Physiol. 105, 369-378.

15 Chuman, L., Fine, L.G., Cohen, A.H. and Sair, M.H., Jr. (19k2) j. Cell Biol, 04, 506-510.

16 Chung, S.D., Alavi, N., Livingstone. D., Hiller. S. and Taub. M. (1982) J. Cell Biol. 95, 118-126.

17 Wilson. P.D. and Horster, M.F. (1983) Am. J. Physior. 244. C166-174. is Straus DS. (19sen in Mhelecular and (ellular Bisklegy of Diatbotes Melitus (Domenin, 3. Mined, S. and LeRoith, D., edst, Vol il. pp. i+3-152. Nan R. Liss New York.

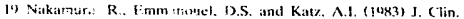

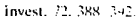

20) Hammetmin. M.R, I : Rogers. S. (1987) Am. J. Physiol. 253. $\mathrm{F} \times+1-\mathrm{F} \times 7$

2f Hammerman. M.R. (1965) Am. J. Physiol. 240. FI-11.

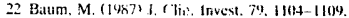

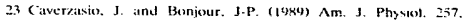
F712-717.

24 Finc, L. (1966) Kidncy Int. 29, 619-6.34.

25 Ifumes, I.D. Ciestinkt. D.A.. Tolinson. L.B. Reiss R. and (ivimbra. T. (1909) (?in. Res. 327, 492A.

26 Haverty. T.P. Kelly. C.J.. Hines. W.H.. Amenala, P.S. Watanabe, M., !larjer. R.A.. Kefilides, V.A. and Neilson, F.G. (I9sk) J. Citl Bitl. 107, 1359-1368.

27 Ziyadeh. F.N.. Snipes. E.R., Watanabe, M.. Alvarez, R.J., Goldfarb, S. and Haverty, T.P. (1990) Am. J. Physiol, 259, F704-714.

28 Ziyideh, F.N.. Simmons, D.A.. Snipes E.R. and Goldfarh, S. (1991; 3. Am. Soc. Nephrol. 1, 1220-1229.

29) Wolf. (i. Killen. P.D. and Neilson, E.G. $(1991)$ (ell Regal. 2 , $219-227$.

30) Furlanetto. R.W. (1942) J. Clin. Endocrinology Metab. 54. 16xt$10 \%$ h.

3) Blazer-Yost, B.1... (ioldfarh. S. zad Z: ateh, F.N. (1991) In Contemporary livues in Nephroh ay (Goldfarb. S. and Ziyadeh. F.N., eds.), Vol. 23. pp. 339-363. Churchill Livingstone' New York.

32 Hammerman, M.R. and Givin. J.R. (1944) Am. J. Physiol. 247. F $4108-417$

33 Pillion, D.J.. Haskell, J.F. and Meezan, E. (19as) Am. J. Physiol. 255. E504-512.

3.4 Hammerman. M.R. (19\%9) Am. J. Physiol. 257. F5013-514.

35 Treadway, J.L. Morrison. B.D., Goldfine. I.R. and Pessin, J.E. (1989) J. Biol. Chem. 264, 21450-21453.

36 Moxham. C.P.. Duronio, V. and Jacobs. S. (1989) J. Biol. Chem. 264. $13238-13244$.

37 So s, M.A., Whittuler. J., Lammers, R.. Ullrich. A. and Siddle. K. $(1,40))$ Biuchem. J. 270, 39, 3-390).

38 Stuart, C.A., Pietryyk, R., Situ, A.K.Q. and Furlanetto, R.W. (1984) J. Clin. Endocrinology Metab, 58. 1-5.

39 Gershberg. H., Heiaemann. H!O. and Stumpf. H.H. (1957) J. Clin. Endt crind. Aetabol. $17.377-385$.

40) Stiles, A.1). Soc tho. J.R.S., D'Ercole A.J. and Smith. H.T.

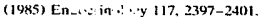

41 Andersson. C. t.. jkottner. A. and Jennische. 5. (1988) Acta Endocrinol. Copenthagen 119, 555-560:

42 Hansson, H-A.. Nilsson, A., Isgaard, J., Billig. H.. isakson, A.. Anderson. J.K. and Rozetl, B. (1988) Histochemistry 89, 413-410. 